Article

\title{
Child-Led Participation: A Scoping Review of Empirical Studies
}

\author{
Tania Mateos-Blanco ${ }^{1, *}$, Encarnación Sánchez-Lissen ${ }^{1}$, Inés Gil-Jaurena ${ }^{2}$, and Clara Romero-Pérez ${ }^{1}$ \\ ${ }^{1}$ Departamento de Teoría e Historia de la Educación y Pedagogía Social, Universidad de Sevilla, Spain \\ ${ }^{2}$ Departamento de Teoría de la Educación y Pedagogía Social, Universidad Nacional de Educación a Distancia (UNED), Spain \\ * Corresponding author (taniamb@us.es)
}

Submitted: 29 September 2021 | Accepted: 9 December 2021 | Published: 20 April 2022

\begin{abstract}
Children's participation is a universal right recognised by the United Nations Convention on the Rights of the Child. This right corresponds to an image of children as social actors because of their relevant role in achieving inclusive, equitable, and sustainable development. Participation can take different forms and levels of involvement: consultative, collaborative, and child-led. This study aimed to explore types and results of child-led participatory practices. A scoping review was carried out to find out what evidence is available on child-led participatory experiences. Based on 674 identified papers, a total of 33 studies met the inclusion criterion. The qualitative analysis employed in this review allowed us to explore the depth and themes of these experiences. The results obtained showed that the experiences analysed differed in (a) the research design and data collection methods of the studies, (b) the age of the participating children, (c) countries in which the experiences took place, (d) specific topics, and (e) outcomes. Moreover, they all shared a non-adult-centric view of children's capacities for transformative action. The review has contributed to improving our understanding of children's transformative capacities based on the possibilities offered by adults when they adopt a child-rights approach and integrate co-participatory approaches, encouraging us to rethink childhood from other cultural codes inspired by equality, recognition, and agency.
\end{abstract}

\section{Keywords}

activism; child advocacy; children's rights; decision making; participation; participatory approach; student empowerment; student participation

\section{Issue}

This article is part of the issue "Promoting Social Inclusive Experiences in Uncertain Times" edited by Ana Belén Cano-Hila (University of Barcelona).

(C) 2022 by the author(s); licensee Cogitatio (Lisbon, Portugal). This article is licensed under a Creative Commons Attribution 4.0 International License (CC BY).

\section{Introduction}

Child-led participatory practices are a clear example of the active role that children can assume as social actors, participating in social and political life in different ways, and in such a way that is different to adults' participation. It is possible that this "generation gap," which also entails differentiated social representations for childhood, youth, and adulthood, explains why social expectations children have regarding the possibilities of action and influence in social and political spheres are lower than those projected by adults onto youth and adult citizenship in general (Liebel, 2020).
If we focus on the political sphere, child-led participation in modern democracies usually develops in a consultative manner, initiated, led, or managed by adults. This is a basic but no less important form of participation in democratic societies, whereby children's citizenship can influence decision-making processes on issues that concern them. Even if not mentioned as such, this basic form of participation is enshrined in the Convention on the Rights of the Child (United Nations Committee on the Rights of the Child, 1989). This international convention positions children as subjects of rights and includes, among others, their right to freedom of expression, thought, conscience and religion, association, leisure, 
play and enjoyment of cultural activities, as well as free and full participation in cultural and artistic life. More recent policy documents, such as the Recommendation on the Participation of Children and Young People Under the Age of 18 (Council of Europe, 2012), are more specific about protecting children's right, promoting, informing, and creating spaces towards this goal. However, advocates of a more deliberative democracy (Adorno, 1998; Dewey, 1916; Freire, 1967) emphasise the need to broaden and extend the involvement of citizens in social and political life to promote changes in the public sphere for the common good (Cussianovich, 2018; Lansdown, 2001, 2011; Liebel, 2013). In this article, we try to provide evidence of research and experience on child-led participatory practices in collaboration with adults.

The second decade of the 21st-century ushers in a new historical era in which the active role of citizens, including children, is taking on a more prominent role. The horizon outlined by the 2030 agenda points to a new global social contract in which civil society becomes more relevant compared to other stages in the development of democratic societies. Reducing inequalities, promoting the social, economic, and political inclusion of all people (regardless of age, gender, disability, race, ethnicity, origin, religion, or economic or other status), eradicating poverty, especially among children, achieving gender equality through the empowerment of women and girls, transforming sustainable consumption and production patterns, the fight against climate change and, with it, the capacity to face responsibilities and facilitate a prosperous future, in solidarity and compatibility with climate security and the limits of the planet, as well as the promotion of peaceful and inclusive societies that enable human development and material prosperity at a global level, synthesise the Sustainable Development Goals that in recent years have catalysed some of the individual and collective actions led by children and adolescents (880 Cities et al., 2017; Croke et al., 2021; Cuevas-Parra, 2017; Hujo \& Carter, 2019; O’Neill, 2010; Rodgers, 2020; Unicef, 2013).

This new social contract on a global scale challenges not only adult citizenship but also children's citizenship, whose relevance and forms of participation take on different tones and forms depending on the countries and their social problems. This is the case in Latin American and African countries, where it is common to think about and promote children's participation from a criticalemancipatory, decolonial, or feminist perspective (social justice, the eradication of poverty and child exploitation, peace and reconciliation, and the empowerment of girls tend to be the focus of a large part of child-led participatory experiences in these countries). This is also the case in North American and Anglo-Saxon countries, which are more focused on a pragmatist-liberal reading of this participation and usually centred on the capacity for representation and protagonism of children in different spheres of social life (school, health, justice, urban planning, research, environment), and in European coun- tries, which offer a guarantee-based approach that is more focused on the protection of the right to children's participation than on its expansion and promotion.

Children's participation means the informed and voluntary involvement of children in any matter directly or indirectly related to them. In practice, it involves children expressing their views, having them taken seriously by adults, and having the opportunity to influence decisionmaking (Lansdown, 2018). Child-led participation, corresponding to Lansdown's (2011) third level, emphasises the protagonist nature of children in decision-making processes adopted from and by children. In this third level of participation, children "jointly establish an associated relationship to assert their interests and rights, where age, gender or class are not discriminatory or exclusionary elements" (Lay-Lisboa \& Montañes-Serrano, 2018, p. 3). The role of adults or institutions is that of an accompanying adult, builder of opportunities and environments conducive to the exercise of such participation, individually or collectively, in order to undertake actions with an impact on the environments in which they coexist.

According to the Convention on the Rights of the Child (United Nations Committee on the Rights of the Child, 1989), children are defined as persons under the age of eighteen, of different genders and abilities, regardless of their lesser or greater social vulnerability. The value of this definition is tied to the very nature of participation, which recognises children as competent social actors and social participants. This theoretical dimension allows us to consolidate the most genuine aspect of participation by identifying children and adolescents as active subjects and not merely passive recipients. From this perspective, the aim is to highlight the importance of child-led participatory processes to achieve a participation model that guarantees the true objective of this process. The value of self-management involves a reflective analysis, awareness, and internalisation of the tasks that allows incorporating all dimensions. With this scoping review, a new contribution is made to childhood studies, especially from the perspective of projects led by children and adolescents themselves.

From a practical perspective, moving forward in participatory projects means using the voice of students as a catalyst for change (Sandoval-Mena et al., 2020), as well as students' own initiatives and strategies to manage that change.

This scoping review, which analyses a series of childled participation projects, is focused preferably in a nonformal educational setting. However, an active, young, and in many cases inexperienced citizen also requires a formal learning model. This gives great value to school education, as this is an essential life stage for the development of active citizenship. If throughout the school stage the foundations of active and constructive listening are laid, learning can be transferred to a different situation. Throughout this process, the guidance of the teacher is vital, so that their training, of greater or lesser 
quality, can lead to the success of this model. Training teachers to acquire the appropriate and applicable tools for each occasion and style of participation should be included in teacher education programmes and, more systematically, incorporated into teacher education curricula. In short, it is essential to articulate teacher training processes around participation (Ceballos-López \& Susinos-Rada, 2014; Saiz-Linares et al., 2019).

Different studies show that the school system is not the best place for learning citizenship and participation (Aguado et al., 2018; Conseil National d'évaluation du système scolaire, 2016). However, schools have the potential to become the most common setting where dialogue is encouraged and children rights and empowerment are promoted (Sandoval-Mena et al., 2020). This provides greater strength and learning for the rest of the non-formal spaces where children and adolescents live together. In this way, following Damon's (1988) philosophy, participation will be truly effective if it is offered an institutional framework that reinforces it and, likewise, if there are projects and public policies that promote it.

This scoping review focuses on child-led participation, which will be discussed in the next section. The aim has been to explore types and results of child-led participatory practices. This scoping review was guided by the following research questions: What types of child-led participatory practices have been corroborated? What kind of issues do they address (e.g., environmental, violence, health, and well-being, etc.)? What role do adults play in child-led participatory processes?

\section{Methodology}

\subsection{Working Definitions}

\subsubsection{Child-Led Participation}

According to Lansdown (2011), children's participation can be classified into three levels: consultative, collaborative, and child-led participation. The types of children's leadership and the role of adults are different at each of these levels. Child-led participation occurs when children are given the space and opportunity to identify issues that concern them, as well as initiate activities and take on decision-making processes for themselves. Adults take on a "dynamizing" role as facilitators and act as support persons so the children can focus on finding the solutions and making the decisions that most directly relate to the issues that affect them and their communities. Adults provide children with information, advice, and support. Non-governmental organisations such as World Vision and Save the Children have in recent years prioritised children's self-leadership in decision-making.

\subsubsection{Types of Child-Led Participation}

In this scoping review, the classification proposed by World Vision has been used to differentiate between various forms of child-led children's participation (Cuevas-Parra, 2017), namely: (a) child-led mobilisation, in which children engage in social movements and participate in public policy debates through campaigns and awareness-raising actions; (b) child-led research, in which children undertake their own research on issues that affect their daily lives, including their immediate community; (c) child-led accountability, in which children monitor local policy and practice and use this information to take action with local policymakers and service providers; and (d) child-led social accountability, which is organised based on a collaborative network of children from different countries and regions. The participatory processes generated through this network enable children to influence, individually and collectively, their communities, countries, and regions.

\subsection{Empirically Exploring Child-Led Participatory Processes}

Recently, the Commission on the Futures of Education (2020), established by UNESCO, has outlined nine ideas to drive education forward in the new post-Covid era. These include prioritising the participation of students and young people so that they take on an active role in social change. Involving them in decision-making processes in matters that affect them (United Nations Committee on the Rights of the Child, 1989) is an excellent indicator of the development of the right to children's participation in practice. Despite the practical complexity and limitations of this right, there are interesting child-led participatory experiences that show another image of children as social actors.

\subsection{Study Design}

A scoping review of the available literature was adopted to respond to the objective and questions of the study. This type of review is used in multidisciplinary scientific fields (e.g., health, social sciences) to answer questions relating to complex multidimensional phenomena or to learn about the available evidence (type and quantity) in a particular area (Munn et al., 2018). They provide an overview and follow a rigorous and systematic process that makes it transparent and replicable (Verdejo et al., 2021). Their usefulness lies in the fact that they synthesise the available evidence (quantitative and qualitative) to understand, in general terms, what is already known about a specific phenomenon. They allow, among other things, to explore the extent, breadth, and nature of research in an area of study.

The methodological strategy adopted in this scoping review follows Arksey and O'Malley (2005), Levac et al. (2010), and the Joanna Briggs Institute (JBI) protocol for scoping reviews (Peters et al., 2020). The PRISMA-ScR protocol developed by Tricco et al. (2018) was also used.

Searches were limited to three databases: Education Resources Information Centre (ERIC), Scopus, and 
the Scientific Electronic Library Online (SciELO). The Participedia platform (https://participedia.net), which is an international online collaborative network that disseminates cases of participatory experiences in the public sphere, was also used for the documentary search.

The search was carried out using keywords extracted from the ERIC thesaurus and completed with other terms used in articles related to the subject. The search terms used were: "empowerment," "child-led," "participation," "participatory approach," "youth-led." Given the amount of content in Spanish in the SciELO database, we also used keywords in Spanish: participación, protagonismo, infantil, adolescente, empoderamiento. To narrow down the search, relationships and combinations between keywords were defined using the Boolean operators "AND," "OR," and "NOT."

Inclusion criteria were as follows: original peerreviewed articles and online documents at the international level that conceptually analysed, evaluated, or described experiences of child-led and adolescent-led participation. Descriptive, evaluative, review, or empirical studies of a quantitative, qualitative, or mixed nature were considered. The search period focused on the period ranging from 2000 to 2020 . The search was limited to English and Spanish.

The exclusion criteria were studies on consultative or collaborative children's participation (either theoretical, evaluative, empirical, or review studies).

The quality of the selected papers was assessed based on the protocol developed by JBI for overview literature reviews (Munn et al., 2018).

For the identification and screening phase of the studies and experiences, each co-author was assigned a database. The search on the Participedia platform was assigned to another co-author. The final phase, which was the final selection of studies, was organised on a peer-to-peer basis among the authors of this article. In this way, each pair of co-authors assessed the potentially eligible papers in this exploratory review, reading the full texts, and crosschecking the eligibility of the pre-selected studies against the pre-established inclusion criteria.

\section{Findings}

A total of 48 complete records were analysed and a total of 33 documents were finally selected for the scoping review. One duplicate record and 16 records that did not fit the specific subject of the review were rejected. Figure 1 provides the flow chart of the scoping review, according to the model proposed by Page et al. (2021).

Of the 33 documents included in the review, 24 were peer-reviewed articles and nine were cases on child-led participatory processes disseminated on the Participedia platform. Most of the studies and experiences correspond to the "child-led research" modality (19 records), followed by "child-led mobilisation" (10 records). A total of four documents corresponded to the "child-led accountability" type. Of the 24 publications selected from the databases, two publications used quantitative methods, 20 used qualitative methods, one applied a mixed methodology, and one adopted the literature review methodology. The studies included in the review differ in (a) research design and data collection methods, (b) age of the participating children and adolescents, (c) countries in which the experiences took place, (d) specific topics, and (e) outcomes (see Supplementary File).

\subsection{Child-Led Accountability}

Of the 33 projects analysed from the selected documents, only four projects a child-led approach in which children monitor policies and service delivery in their community and propose improvement actions to governors and service providers. Equity, empowerment, and social justice are the issues of greatest interest in the analysed projects. Two of the reviewed experiences show that this type of leadership enables children to work collectively, to engage with their community, and to demonstrate to the adult world that participatory approaches can be transferred to important decisionmaking spaces (Participedia, 2008b, 2008c).

Examples of child-led social accountability can be found in the projects led by Walker and Saito (2011) and Camden Children in Care Council's Deliberative Forums (Participedia, 2008a). Both are based on a model of networking and collaboration between young leaders from different countries to promote campaigns for the development and improvement of their communities: promoting programmes and places for youth participation or improving the provision of educational services to at-risk groups. In terms of impact, these experiences demonstrate an increase in community awareness, political socialisation, and personal development of children.

\subsection{Child-Led Mobilisation}

Ten of the selected documents-eight papers and two Participedia experiences-correspond to the child-led mobilisation typology: engagement and participation in awareness campaigns, actions, and social movements. Regarding the issues addressed, most projects deal with human/children rights, environmental, or health issues.

The projects show different ways and a broad range of children mobilisation: youth-led videos for raising awareness about sex education (Yang \& MacEntee, 2015); a game-based approach for promoting children awareness and engagement in environmental urban planning (Giraldo Cadavid, 2018; Polo-Garzón \& López-Valencia, 2020), or the use of children drawings for a similar purpose, in relation to climate change (Demneh \& Darani, 2020); the use of diverse creative and popular education methods for saving children and adolescents from child labour (Alberto et al., 2012); a sportbased approach for female empowerment (Participedia, 


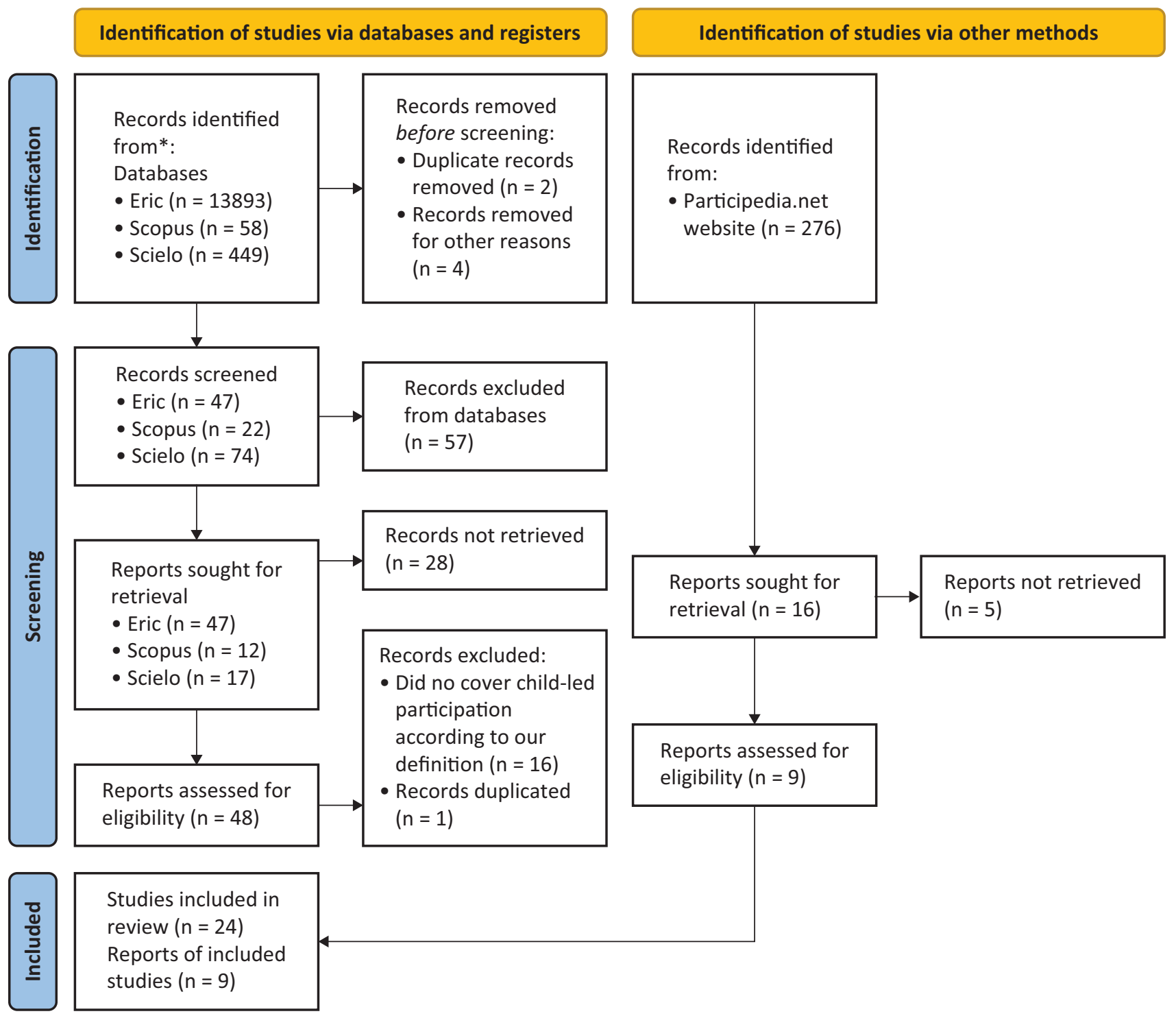

Figure 1. PRISMA flow diagram for scoping reviews.

2020b); the use of child-led climate change legal cases for human rights education (Grover, 2018); youth-led protests for defending public schools (King et al., 2018); youth-led participatory budgeting (Augsberger et al., 2019); and the inclusion of children representatives in public debates at national level through different governance structures (Participedia, 2020a).

The projects, despite the diverse topics and approaches they show, highlight the importance of children and youth agency, empowerment, and collective action beyond awareness-raising; thus the experiences deal with mobilisation of children and youth as active citizens engaged in public issues they are concerned about, and not only with the (also relevant) appeal to awareness at a cognitive level.

About the role of adults in these child-led mobilisation experiences, the review highlights, on one hand, their contribution as supporters of children participation and as creators of conditions for actual participa- tion. On the other hand, given that child-led mobilisation aims to have an impact on public policies, two elements are presented as crucial for the success of the practices: (a) the adults' representation of children as agents and active citizens and (b) the commitments of adults with the proposals that children make.

\subsection{Child-Led Research}

Most of the research included in this typology reflects the difference between conducting research related to children and conducting it with them, assuming a protagonist and leading role (Cuevas-Parra \& Tisdall, 2019). Therefore, the value of offering them the opportunity to engage in research processes is underlined as a steppingstone to a scenario of engagement and action that generates capacity for improvement in their environment and change in attitudes and beliefs (Kervin \& Obinna, 2010). In child-led research, the role of children as active 
researchers is as important as the role of adults as facilitators and accomplices in the participatory action (Cumbo et al., 2019; Participedia, 2014a, 2017) or, in any case, as administrators (Cuevas-Parra \& Tisdall, 2019).

This type of practices extends beyond the school environment and includes all those people who have been marginalised by some personal or social conflict and who are to be given a voice through a model of investigative participation (Carroll et al., 2019; Graham et al., 2017). But its success will come if ultimately the designed research can influence practice and the policy arena (Kellett, 2011) by giving young people a voice to achieve a model of empowerment (Participedia, 2014b; Trott, 2020), as designed by Zimmerman (1995), in a threefold perspective, with intrapersonal, interactional, and behavioural components.

The literature shows that these research-focused participatory experiences can be articulated through a methodology called youth participatory action research (YPAR; see Cammarota \& Fine, 2008; Chevalier \& Buckles, 2013; Ozer, 2017; Ozer et al., 2010). The main area in which the selected studies are developed is the school environment, with topics such as school absenteeism, social inequalities, health, and social justice. Several of the studies about participatory projects developed from YPAR highlight the potential of this methodology as a way to foster civic engagement of young people, the democratisation of knowledge, critical thinking, institutional trust, as well as social, emotional, and cognitive development of young people (Buckley-Marudas \& Soltis, 2019; Chou et al., 2015; Participedia, 2016; Prati et al., 2020). Likewise, research such as that of Abraczinskas and Zarrett (2020), Anselma et al. (2020), Chou et al. (2015) demonstrate YPAR's effectiveness in promoting the leadership of vulnerable children and young people in participatory processes that enable them to propose actions in line with their needs and interests and to empower themselves.

In all of the three versions, we can verify that the projects relate to the involvement of the adult, who participates as a mediator in the activity, as a referee who lets the "game" continue, intervening only in strictly necessary actions. The adult person has an integrating and, at the same time, collaborative role that implies that they are qualified for the performance of these tasks, that they have the necessary training to strengthen participatory processes, and that the adult does not interfere with the integrity of a project whose leadership relies on the children and adolescents. Institutional processes can help strengthen this path (Pavez-Soto \& Sepúlveda Kattan, 2019).

\section{Conclusion}

Our article aimed to provide evidence of various forms of children's participation led by children themselves. The results of our research show that children can undertake transformative actions in their social environment, if the adult world provides them with the opportunities to do so and if, in addition, the ways of thinking about children's participation and putting it into practice with children themselves are updated (McMellon \& Tisdall, 2020; Nolas, 2015). This leads to the need to rethink children's participation from epistemological keys more closely linked to the daily lives of children and adolescents, and to methodologies more deeply rooted in popular and community education, rather than from the more institutional logics inherent to a governance approach. Indeed, the experiences analysed in this review share this renewed vision of childhood and children's participation.

The results of this research support the idea of the diversity of settings in which child-led participation takes place. The analysed documents show that environmental and urban planning issues are the scenarios where childled participatory processes are most present. This is probably explained by the greater environmental awareness that occurs during childhood and adolescence, and by the opportunities offered by children's environment (e.g., at school) to foster processes of transformation and change based on the their proposals.

This research will serve as a basis for future studies. One of the lines of work to be developed is related to the age of the participants and their relationship with child-led participatory processes. As various studies have shown, age conditions such leadership. In this sense, we agree with Sheridan and Pramling (2001) and Stephenson (2002) who acknowledge the difficulty of completing a fully self-directed model if the participants are younger than 5-6 years old, since, in such cases, children may decide what to play with, but it is the responsibility of the adult to formalise and make decisions about everything related to the organisation, routines, and activities in the learning space (Manassakis, 2020). This dilemma leads several authors to question whether childled participatory research can be considered research at all, given that the process requires responsibility and demands knowledge that, at certain ages, children do not yet possess (Hammersley, 2017; Kellett, 2011). In this sense, it would be useful to explore to what extent age becomes a potential barrier to, specifically, child-led participation (and other forms of participation) and to what extent this dilemma about age and competence is biased from an adult-centric perspective, or even an ageist and ableist discourse that hinders the responsibility of adults to create adequate conditions for children participation.

The second line of study that emerges from this review is related to the evaluation of participatory experiences implemented by the children themselves. The experiences described in the documents selected for the review provide data on the evaluation of the participatory processes carried out but do not provide evidence of the final results obtained, knowing that they are part of account rendering (Kellett, 2011) and, more importantly, that this type of information is essential to strengthening the credibility of these new ways of 
conceiving and putting into practice children's participation. It would also be of interest to evaluate the influence that place and host institution may have on participation (Cumbo et al., 2019) in relation to the effectiveness and timeliness of child-led participation. The non-formal nature of the environments in which it takes place contributes to greater freedom of action. However, those projects incardinated in specifically formal environments would participate in a model instrumented by institutional characteristics and values (Prosser-Bravo et al., 2020). Therefore, it seems equally necessary to adequately train children and adolescents in participation matters, and also the adults who guide the processes, together with the institution that hosts them.

It would therefore be interesting to evaluate the effects of these child-led participatory projects-for example, by providing evidence of the impact, over time, of such transformative experiences on individual children and its magnitude. This will allow for a redoubling of efforts in the implementation of these forms of children's participation in which children play a greater role (Ho et al., 2015). Only one longitudinal study and one evaluative study of the programme were found in the review.

The most important limitation of this scoping review lies in the fact of the documentary basis on which the records have been accessed. Documents such as doctoral theses, academic papers, and NGO and social organisations reports have not been consulted, which limits the number of sources consulted.

Nevertheless, this review suggests practical implications at educational and socio-cultural levels, highlighting the importance of training in participatory methodologies for both adults and the children involved in these processes and renewing the way we look at children and recognise that children and adolescents have the capacity for agency. The studies chosen for this review provide evidence especially of the former: According to Hulshof (2019) and Purdy and Spears (2020), by adopting these participatory approaches in project evaluation, decision-making, and research, adults relinquish traditional adult-centred hierarchies of power and knowledge and place children at the centre of the action. Our findings encourage us to rethink children from other cultural codes inspired by equality, recognition, and agency.

\section{Acknowledgments}

This work was supported by the Ministry of Science and Innovation of the Government of Spain, the European Regional Development Fund, and the Spanish State Research Agency under the project Childhood and Participation: Diagnosis and Proposals for an Active and Inclusive Citizenship (RTI2018-098821-B-I00).

\section{Conflict of Interests}

The authors declare no conflict of interests.

\section{Supplementary Material}

Supplementary material for this article is available online in the format provided by the author (unedited).

\section{References}

880 Cities, Bernard van Leer Foundation, \& Urban 95. (2017). Building better cities with young children and families. How to engage our youngest citizens and families in city building: A global scan of best practices. https://bit.ly/36YCTyW

Abraczinskas, M., \& Zarrett, N. (2020). Youth participatory action research for health equity: Increasing youth empowerment and decreasing physical activity access inequities in under-resourced programs and schools. American Journal of Community Psychology, 66(3/4), 232-243. https://doi.org/10.1002/ajcp. 12433

Adorno, T. (1998). Educación para la emancipación: Conferencias y conversaciones con Helmut Becker (1959-1969) [Education for emancipation: Lectures and conversations with Helmut Becker (1959-1969)]. Ediciones Morata. https://bit.ly/2Vb1cXq

Aguado, T., Melero, H. S., \& Gil-Jaurena, I. (2018). Espacios y prácticas de participación ciudadana: Propuestas educativas desde una mirada intercultural [Spaces and practices of citizen participation: Educational proposals from an intercultural perspective]. RELIEVE, 24(2). http://doi.org/10.7203/relieve.24.2. 13194

Alberto, M. d. F. P., Borges, R. S., Pessoa, M. C. B., de Sousa, J. M. L., de Araújo, P. F. M., Vaz, R. d. O. F., \& Mendes, L. J. d. A. (2012). Programa de erradicação do trabalho infantil: Ações extensionistas e protagonismo [The child labour eradication programme: Extensionist actions and youth empowerment]. Psychology: Ciência e Profissão, 32(2), 516-531. https:// doi.org/10.1590/s1414-98932012000200018

Anselma, M., Chinapaw, M., \& Altenburg, T. (2020). Not only adults can make good decisions, we as children can do that as well evaluating the process of the youth-led participatory action research "kids in action." International Journal of Environmental Research and Public Health, 17(2). https://doi.org/ 10.3390/ijerph17020625

Arksey, H., \& O'Malley, L. (2005). Scoping studies: Towards a methodological framework. International Journal of Social Research Methodology, 8(1), 19-32. https://doi.org/10.1080/1364557032000119616

Augsberger, A., Gecker, W., \& Collins, M. E. (2019). We make a direct impact on people's lives: Youth empowerment in the context of a youth-led participatory budgeting Project. Journal of Community Psychology, 47(3), 462-476. https://doi.org/10.1002/jcop. 22131

Buckley-Marudas, M. F., \& Soltis, S. (2019). What youth care about: Exploring topic identification for 
youth-led research in school. The Urban Review, 52(2), 331-350. https://doi.org/10.1007/s11256019-00530-5

Cammarota, J., \& Fine, M. (2008). Revolutionizing education: Youth participation action research in motion. Routledge. https://doi.org/10.4324/978020 3932100

Carroll, P., Witten, K., Asiasiga, L., \& Lin, E.-Y. (2019). Children's engagement as urban researchers and consultants in Aotearoa/New Zealand: Can it increase children's effective participation in urban planning? Children and Society, 33(5), 414-428. https://doi.org/ 10.1111/chso.12315

Ceballos-López, N., \& Susinos-Rada, T. (2014). La participación del alumnado en los procesos de formación y mejora docente: Una mirada a través de los discursos de orientadores y asesores de formación [Students participation during teacher training and improvement processes: Looking through the discourses of school counsellors and training advisors]. Profesorado: Revista de currículum y formación del profesorado, 18(2), 228-244. https://bit.ly/3p1sr26

Chevalier, J. M., \& Buckles, D. J. (2013). Participatory action research. Routledge.

Chou, F., Kwee, J., Lees, R., Firth, K., Florence, J., Harms, J., Raber, M., Stevens, T., Tatomir, R., Weaver, C., \& Wilson, S. (2015). Nothing about us without us! Youthled solutions to improve high school completion rates. Educational Action Research, 23(3), 436-459. https://doi.org/10.1080/09650792.2015.1013047

Commission on the Futures of Education. (2020). Education in a post-COVID world: Nine ideas for public action. UNESCO. https://bit.ly/3ByKvWP

Conseil National d'évaluation du système scolaire. (2016). Éducation à la citoyenneté à l'école-Rapport Scientifique avril 2016 politiques, pratiques scolaires et effets sur les élèves [Citizenship education education in schools-Scientific report April 2016: Policies, school practices and effects on students]. CNESCO. https://bit.ly/3F7pFze

Council of Europe. (2012). Recommendation on the participation of children and young people under the age of 18. https://rm.coe.int/168046c478

Croke, R., Dale, H., Dunhill, A., Roberts, A., Unnithan, M., \& Williams, J. (2021). Integrating sustainable development and children's rights: A case study on Wales. Social Sciences, 10(3). https://doi.org/ 10.3390/socsci10030100

Cuevas-Parra, P. (2017). Children and young people's participation. An essential approach for ending violence against children. World Vision. https://bit.ly/ 3wW9IMF

Cuevas-Parra, P., \& Tisdall, E. K. M. (2019). Child-led research: Questioning knowledge. Social Sciences, 8(2). https://doi.org/10.3390/socsci8020044

Cumbo, B. J., Eriksson, E., \& Iversen, O. S. (2019). The "least-adult" role in participatory design with children. In A. Lugmayr, M. Masek, M. Reynolds, M.
Brereton, R. Kelly, V. Roto, I. Richardson, H. Shen, C. Parker, N. Ahmadpour, J. Li Tay, J. Donovan, \& S. Perrault (Eds.), OZCHI'19: Proceedings of the 31st Australian conference on human-computer-interaction (pp. 73-84). Association for Computing Machinery. https://doi.org/10.1145/3369457.3369464

Cussianovich, A. (2018). Paradigms of childhood cultures as expressions of power. Training Institute for Working Children and Adolescents "Nagayama Norio" (INFANT). https://bit.ly/3BAdeuj

Damon, W. (1988). Socialization and individuation. In G. Handel (Ed.), Childhood socialization (pp. 3-10). De Gruyter.

Demneh, M. T., \& Darani, Z. H. (2020). From remembering to futuring: Preparing children for anthropocene. Journal of Environmental Studies and Sciences, 10(4), 369-379. https://doi.org/10.1007/ s13412-020-00634-5

Dewey, J. (1916). Democracy and education: An introduction to the philosophy of education. Macmillan. https://bit.ly/3BzPFII

Freire, P. (1967). Educacao como practica do libertade [Education for critical consciousness]. Paz e Terra. https://bit.ly/36U2hWv

Giraldo Cadavid, D. A. (2018). Propuesta pedagógica para la participación infantil en la gestión ambiental urbana [Pedagogical proposal for child participation in urban environmental management]. Nómadas, 49 155-171. https://doi.org/10.30578/nomadas.n49a9

Graham, A., Simmons, C., \& Truscott, J. (2017). “I'm more confident now, I was really quiet": Exploring the potential benefits of child-led research. International Journal of Qualitative Studies in Education, 30(2), 190-205. https://doi.org/10.1080/09518398. 2016.1242803

Grover, S. (2018). Rights education and children's collective self-advocacy through public interest litigation. Human Rights Education Review, 1(1), 65-83. https://doi.org/10.7577/hrer.2691

Hammersley, M. (2017). Childhood studies: A sustainable paradigm? Childhood, 24(1), 113-127. https:// doi.org/10.1177/0907568216631399

Ho, E., Clarke, A., \& Dougherty, I. (2015). Youth-led social change: Topics, engagement types, organizational types, strategies, and impacts. Futures, 67, 52-62. https://doi.org/10.1016/j.futures.2015.01.006

Hujo, K., \& Carter, M. (2019). Transformative change for children and youth in the context of the 2030 agenda for sustainable development (Innocenti Working Paper 2019-02). Unicef Office of Research. https:// bit.ly/3iDMr7T

Hulshof, H. (2019). Child participation in evaluating social protection projects: Do global development actors walk the talk? Progress in Development Studies, 19(1), 1-20. https://doi.org/10.1177/146499 3418805170

Kellett, M. (2011). Empowering children and young people as researchers: Overcoming barriers and build- 
ing capacity. Child Indicators Research, 4(2), 205-219. https://doi.org/10.1007/s12187-010-9103-1

Kervin, D., \& Obinna, J. (2010). Youth action strategies in the primary prevention of teen dating violence. Journal of Family Social Work, 13(4), 362-374. https:// doi.org/10.1080/10522158.2010.492499

King, A., Warren, M. R., Bien-Aine, M., Gowda, S., Kelly, K., \& Moyer, J. (2018). Youth leadership in the Boston public school walkout movement [Paper presentation]. Annual Meeting of the American Educational Research Association, New York City, NY, United States. https://bit.ly/3vXkgWJ

Lansdown, G. (2001). Promoting children's participation in democratic decision-making. Innocenti Research Centre; Unicef. https://bit.ly/36VG4av

Lansdown, G. (2011). Every child's right to be heard: A resource guide on the UN Committee on the Rights of the Child General Comment No 12. Save the Children UK. https://bit.ly/3eP2lv7

Lansdown, G. (2018). Conceptual framework for measuring outcomes of adolescent participation. Unicef. https://bit.ly/3BNmXgX

Lay-Lisboa, S., \& Montañes-Serrano, M. (2018). De la participación adultocéntrica a la disidente: La otra participación infantil [From adult-centric to dissident participation: The other childhood participation]. Psicoperspectivas, 17(2). https://doi.org/10.5027/ psicoperspectivas-vol17-issue2-fulltext-1176

Levac, D., Colquhoun, H., \& O'Brien, K. (2010). Scoping studies: Advancing the methodology. Implementation Science, 5(1). https://doi.org/10.1186/17485908-5-69

Liebel, M. (2013). Niñez y justicia social: Repensando sus derechos [Children and social justice: Rethinking their rights]. Pehuén Editores. https://bit.ly/3y2z2N8

Liebel, M. (2020). Repúblicas de niños: Desafíos del autogobierno infantil [Children's republics: Challenges of children's self-government]. RES-Revista de Educación Social, 31, 322-362. https://bit.ly/3kPXs8W

Manassakis, E. S. (2020). Children's participation in the organisation of a kindergarten classroom. Journal of Early Childhood Research, 18(1), 18-28. https://doi. org/10.1177/1476718×19882714

McMellon, C., \& Tisdall, E. K. M. (2020). Children and young people's participation rights: Looking backwards and moving forwards. The International Journal of Children's Rights, 28(1), 157-182. https://doi. org/10.1163/15718182-02801002

Munn, Z., Peters, M. D. J., Stern, C., Tufanaru, C., McArthur, A., \& Aromataris, E. (2018). Systematic review or scoping review? Guidance for authors when choosing between a systematic or scoping review approach. BMCMedical Research Methodology, 18(1). https://doi.org/10.1186/s12874-018-0611-x

Nolas, S. M. (2015). Children's participation, childhood publics and social change: A review. Children \& Society, 29(2), 157-167. https://doi.org/10.1111/chso. 12108
O’Neill, K. (2010). Speaking out, being heard. Experiences of child participation and accountability to children from around the world. Save the Children Foundation. https://bit.ly/3y0J69l

Ozer, E. J. (2017). Youth-led participatory action research: Overview and potential for enhancing adolescent development. Child Development Perspectives, 11(3), 173-177. https://doi.org/10.1111/cdep.12228

Ozer, E. J., Ritterman, M., \& Wanis, M. (2010). Participatory action research (PAR) in middle school: Opportunities, constraints, and key processes. American Journal of Community Psychology, 46, 152-166. https:// doi.org/10.1007/s10464-010-9335--8

Page, M. J., McKenzie, J. E., Bossuyt, P. M., Boutron, I., Hoffmann, T. C., Mulrow, C. D., Shamseer, L., Tetzlaff, J. M., Akl, E. A., Brennan, S. E., Chou, R., Glanville, J., Grimshaw, J. M., Hróbjartsson, A., Lalu, M. M., Li, T., Loder, E. W., Mayo-Wilson, E., McDonald, S., . . . Moher, D. (2021). The PRISMA 2020 statement: An updated guideline for reporting systematic reviews. BMJ, 372(71). https://doi.org/10.1136/bmj.n71

Participedia. (2008a). Camden children in care council's deliberative forums. https://bit.ly/3y50E4a

Participedia. (2008b). Everyone counts: Youth participatory budgeting, Walsall. https://bit.ly/3i3ejmH

Participedia. (2008c). The children's fund. https://bit.ly/ 2WiQtus

Participedia. (2014a). Voices that build: Proposals and deliberations on children's issues. https://bit.ly/ $3 k T u J 2 R$

Participedia. (2014b). Campaspe: Our future. https://bit. ly/3y4zhqJ

Participedia. (2016). MH: 2 K youth mental health engagement. https://bit.ly/3ByQdll

Participedia. (2017). Watchdog clubs: Students monitoring school health in El Recreo. https://bit.ly/2WaP09I

Participedia. (2020a). Emerging responses to children's rights during Covid-19 in Mombasa. https://bit.ly/ 3yiip09

Participedia. (2020b). Engaging girls through dialogue, community scorecards and advocacy to combat early pregnancy. https://bit.ly/3kSBSjQ

Pavez-Soto, I., \& Sepúlveda Kattan, N. (2019). Concepto de agencia en los estudios de infancia: Una revisión teórica [Concept of agency in childhood studies: A theoretical review]. Sociedad e Infancias, 3, 193-210. https://doi.org/10.5209/soci.63243

Peters, M. D. J., Marnie, C., Tricco, A. C., Pollock, D., Munn, Z., Alexander, L., McInerney, P., Godfrey, C., \& Khalil, H. (2020). Updated methodological guidance for the conduct of scoping reviews. JBI Evidence Synthesis, 18(10), 2119-2126. https://doi.org/ 10.11124/jbies-20-00167

Polo-Garzón, C., \& López-Valencia, A. P. (2020). La participación infantil en proyectos urbanos: El juego en espacios públicos para la promoción del aprendizaje de conceptos ambientales [Children's participation in urban projects: Playing in public spaces for the pro- 
motion of the learning of environmental concepts]. Revista de Arquitectura, 22(2), 126-140. https://doi. org/10.14718/revarq.2020.2691

Prati, G., Mazzoni, D., Guarino, A., Albanesi, C., \& Cicognani, E. (2020). Evaluation of an active citizenship intervention based on youth-led participatory action research. Health Education \& Behavior, 47(6), 894-904. https://doi.org/10.1177/1090198 120948788

Prosser-Bravo, G., Salazar-Sepúlveda, M. S., Pérez-Tello, S., Pérez-Lienqueo, M., \& Prosser-González, C. (2020). Evaluación de un programa de educación ambiental desde la voz del alumnado [Evaluation of an environmental education programme through the voices of students]. Revista Latinoamericana de Ciencias Sociales, Niñez y Juventud, 18(2), 1-26. https://doi. org/10.11600/1692715x.18206

Purdy, N., \& Spears, B. (2020). Co-participatory approaches to research with children and young people. Pastoral Care in Education, 38(3), 187-190. https://doi.org/10.1080/02643944.2020.1788816

Rodgers, D. (2020). Children in social movements: Rethinking agency, mobilization, and rights. Routledge. https://doi.org/10.4324/9781003014294

Saiz-Linares, Á., Ceballos-López, N., \& Susinos-Rada, T. (2019). Voz del alumnado y mejora docente: Una investigación en centros educativos en Cantabria [Student voice and teacher improvement: A research in schools in Cantabria]. Revista Complutense de Educación, 30(3), 713-728. https://doi.org/10.5209/rced.58883

Sandoval-Mena, M., Simón Rueda, C., \& Echeita Sarrionandia, G. (2020). ¿Qué me ayuda a aprender y participar? Herramientas para recoger las voces de los estudiantes [What helps me learn and participate? Tools for collecting student voices]. Revista de Educación Inclusiva, 13(1), 12-27. https://bit.ly/3IbKBXV

Sheridan, S., \& Pramling, I. (2001). Children's conceptions of participation and influence in preschool: A perspective on pedagogical quality. Contemporary Issues in Early Childhood, 2(2), 169-194. https://doi. org/10.2304/ciec.2001.2.2.4

Stephenson, A. (2002). Opening up the outdoors: Explor- ing the relationship between the indoor and outdoor environments of a centre. European Early Childhood Education Research Journal, 10(1), 29-38. https:// doi.org/10.1080/13502930285208821

Tricco, A. C., Lillie, E., Zarin, W., O’Brien, K. K., Colquhoun, H., Levac, D., Moher, D., Peters, M., Horsley, T., Weeks, L., Hempel, S., Akl, E. A., Chang, C., McGowan, J., Stewart, L., Hartling, L., Aldcroft, A., Wilson, M. G., Garritty, C., . . . Straus, S. E. (2018). PRISMA extension for scoping reviews (PRISMA-SCR): Checklist and explanation. Annals of Internal Medicine, 169(7), 467-473. https://doi.org/10.7326/M18-0850

Trott, C. D. (2020). Children's constructive climate change engagement: Empowering awareness, agency, and action. Environmental Education Research, 26(4), 532-554. https://doi.org/10.1080/13504622.2019. 1675594

Unicef. (2013). Unicef research for children: From evidence to action. Innocenti Publications. https://bit. ly/3BwiXRU

United Nations Committee on the Rights of the Child. (1989). Adopted and opened for signature, ratification and accession by General Assembly resolution 44/25 of 20 November 1989, entry into force 2 September 1990, in accordance with article 49. https://bit.ly/3iEgHjO

Verdejo, C., Tapia-Benavente, L., Schuller-Martínez, B., Vergara-Merino, L., Vargas-Peirano, M., \& SilvaDreyer, A. M. (2021). What you need to know about scoping reviews. Medwave, 21(02), 8144-8144. https://doi.org/10.5867/medwave.2021.02.8144

Walker, R. C., \& Saito, R. N. (2011). You are here: Promoting youth spaces through community mapping. Afterschool Matters, 14, 30-39. https://bit.ly/3pdFDRe

Yang, K.-H., \& MacEntee, K. (2015). "Use condoms for safe sex!" Youth-led video making and sex education. Sex Education, 15(6), 613-625. https://doi.org/ 10.1080/14681811.2015.1051179

Zimmerman, B. J. (1995). Self-efficacy and educational development. In A. Bandura (Ed.), Selfefficacy in changing societies (pp. 202-231). Cambridge University Press. https://doi.org/10.1017/ CB09780511527692.009

\section{About the Authors}

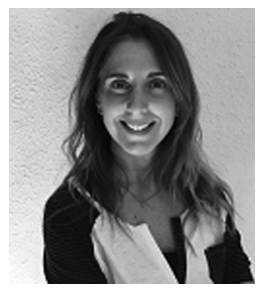

Tania Mateos-Blanco (PhD in education) is an assistant professor at the Theory and History and Social Pedagogy Department of the University of Seville (Spain). She is a member of the research group "Emotional Education and Dramatisation" (HUM-708). Her research activity has been developed in the following lines: cultural diversity and interculturality, narrative applied to education, employability and vocational training, as well as emotional education.

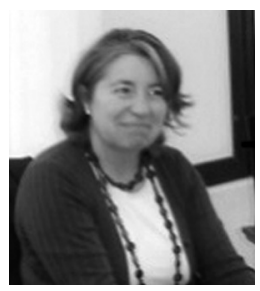

Encarnación Sánchez-Lissen (PhD in education) is an associate professor in the Theory and History of Education and Social Pedagogy Department at the University of Sevilla (Spain). She is a member of the Comparative Education Research Group of Seville (GIECSE) and her main publications, teaching, and research are focused on comparative education, more specifically on an international perspective on teacher training, educational policies, and educational theory. 

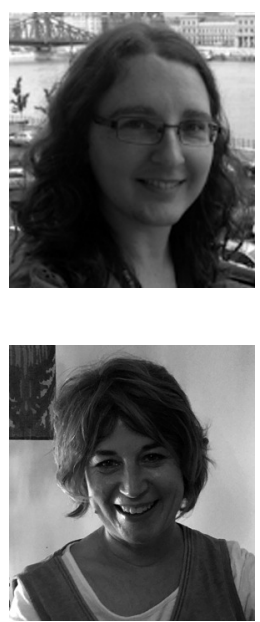

Inés Gil-Jaurena ( $\mathrm{PhD}$ in education) is an associate professor in the Theory of Education and Social Pedagogy Department at the National Distance Education University (UNED), Spain. She is a member of the INTER research group in intercultural education. Her research interests are focused on social pedagogy, community development, citizenship, and participation from an educational perspective.

Clara Romero-Pérez (PhD in education) is an associate professor of philosophy and theory of education at the University of Sevilla. She holds a master's degree in university pedagogy and university teaching from the University of Liège (Belgium). Head of GRieeD (research group on emotional education and dramatization), her research lines include socio-affective education and educational environment, time and education, education theory, and education philosophy. 